\title{
Gender, Academic Level-based Comparative Study on University Students' Epistemological Beliefs towards English Language Learning
}

\author{
AbduIRahman A. Al Asmari, Assistant professor, \\ English Language Center, Taif University \\ Nasrah Mahmoud Ismail, Assistant professor,
}

English Language Center, Taif University

\section{Abstract}

The present study investigated the effects of gender and students academic levels on their epistemological beliefs towards learning English. A total of 547 of English-major students at a Saudi University, including 184 males and 363 females whose levels ranged from 1st to 7th participated in this study. The primary aim of the study was to explore whether there were significant differences in the epistemological beliefs system among two learners groups according to variables such as gender and academic levels. Students were asked to answer questions on the Belief Questionnaire. Students answered each item statement using a 4-point Likert-scale that ranged from 1 (strongly disagree) to 4 (strongly agree). Results were statistically analyzed using, descriptive statistics, ANOVA and the t-test. Analysis results showed that there were differences between English-major students according to their academic levels in their beliefs in subscale 2 (beliefs about a traditional orientation to learning English) and the total score. The results also indicated that there were no differences between males and females towards learning English in their epistemological beliefs except in subscale 3 (the beliefs about the quality and sufficiency of classroom instruction for learning English) and in total scores. Findings in general indicated that all the participants had epistemological positive beliefs towards learning English. These positive epistemological beliefs help the students to learn easily and achieve high GPA. Such results also bring to the fore implications that help the teachers draw suitable strategies with their students inside the classroom.

Keywords: University students 'epistemological beliefs, English-major students, males and females, Saudi language learners

\section{Epistemological Beliefs about English language learning}

There seems a consensus among language learning researchers on the importance of learners' beliefs in Foreign Language Learning (Amuzie \& Winke, 2009; Horwitz, 1987, 1988; Kern, 1995). Horwitz (1987) suggested that erroneous or negative beliefs about language learning may lead to the use of less effective learning strategies. White (1999) also concluded that beliefs are instrumental in defining tasks and play a critical role in behaviour. Moreover, the beliefs systems learners hold or develop 
help them adapt to new environments to define what is expected of them and to act in accordance with those understandings. Drawing on cognitive psychology, Flavell (1976, 1979, and 1987) argued that learners' beliefs are a subcomponent of the metacognitive knowledge that concerns one's own cognitive processes and products or anything related to them. Like other forms of metacognitive knowledge, the beliefs a learner holds about language learning are said to be stable because they can be regarded as a permanent part of the learner's store of knowledge (Wenden, 1999, 2001). However, the assumption that beliefs are stable overlooks the important impact of external experience and learning contexts on learners' beliefs (Amuzie \& Winke, 2009; Barcelos, 2003). Several studies have reported that learners' beliefs change over time (Tanaka \& Ellis, 2003) under different contexts such as study-abroad (Amuzie and Winke, 2009; Gao, 2008), or in group processes (Chang, 2007).

Students come into class with certain epistemological beliefs and misconceptions about language learning and those beliefs may hinder language learning (Green, 1993; Horwitz, 1988; Mantle-Bromley, 1995; Phillips, 1991). Therefore, students have to be encouraged to express their beliefs for both themselves and their teachers. Doing so would allow learners to consider why they are participating in certain activities, how these activities help them learn English, and what use they can make of them both for academic purposes and outside of the classroom (Bulut \& Durak, 2002; Ariogul, Unal, \& Onursal, 2009).

\section{Aim and scope of the study}

The present study aimed to investigate the effects of gender and students' academic levels on students' epistemological beliefs towards English language learning. This included looking into beliefs about contemporary, beliefs about a traditional orientation to learning English, beliefs about the quality and sufficiency of classroom instruction for learning English, and beliefs about foreign-language aptitude and difficulty. The investigation was based on a modified model of beliefs (Sakui \& Gaies, 1999). 
There is little in the existing literature which focuses specifically on the language learning beliefs of English-major students in the Arabic contexts and at the university level. Although several researchers have studied the beliefs in different countries that learn English as a second or foreign language (e.g., Ryan, 1984; Dole \& Sinatra, 1994; Ellis, 2008), a few have examined the effects of gender and academic levels as factors affecting beliefs, especially EFL contexts in the Arab world. To the best of the researchers' knowledge, the effects of gender and students' academic levels on the beliefs toward language learning seem to be highly under-researched, especially in EFL context within Arab Countries. As teachers for English as a foreign language for many years, the researchers noticed that some students in the English Department seemingly have low motivation and different beliefs. However, these beliefs might be unlimited, positive or negative. In addition, there is a kind of contradiction among the previous studies where some studies mentioned that there were differences between males and females (e.g., Magolda, 1992; Belenky, et al., 1986; 1985), while others argued that there were no important gender differences (e.g. Hofer \& Pintrich, 1997; Pintrich, 2002). Needless to say, outcomes of previous studies aroused the researchers' curiosity to do this research to find out to what extent gender and students' academic levels affect on their beliefs. Accordingly, this study addressed the following questions:

1. Do the students have positive beliefs toward English language learning?

2. Do the students' academic levels have any impact on their beliefs toward learning English?

3. Does the students' gender have any effect on their beliefs towards learning English?

\section{Definition of Terms}

For the purpose of this research the following terms were defined:

\section{Epistemological beliefs about English language learning}

Epistemological beliefs are individuals' conceptions of intellectual efforts based on experiences, which are held to be true. Beliefs represent knowledge, arouse emotion, and guide behaviors (Harvey, 1986). Students 'beliefs systems consist of 
four underlying factors, which are: (a) beliefs about a contemporary communicative orientation to learning English; (b) beliefs about a traditional orientation to learning English; (c) beliefs about the quality and sufficiency of classroom instruction for learning English. (d) beliefs about foreign-language aptitude and difficulty (Sakui \& Gaies 1999).

Epistemological beliefs also defined by the researchers as a collection of students' thoughts about their learning English language.

Students' Educational Academic Levels consist of eight academic levels distributed over four years. Each year, the student studies two academic levels in two semesters. For the graduation, the student has to complete eight academic levels.

\section{Theoretical foundation}

Beliefs are a central construct in every discipline which deals with human behavior and learning. In the psychological literature, there is a rich body of theoretical and empirical work on beliefs. Different theoretical orientations and concerns have produced somewhat different views of the nature of beliefs (Dole \& Sinatra, 1994). Beliefs can be defined broadly as "psychologically held understandings, premises, or propositions about the world that are felt to be true" (Richardson, 1996, p. 105). In cognitive psychology, beliefs about learning have been viewed as a component of metacognitive knowledge (Wenden, 1998). Flavell, (1979), (1985), \& (1987), for example, viewed beliefs as a part of self-knowledge, which includes all that individuals understand about themselves as learners and thinkers, including their learning goals and needs. A related view came from Alexander, Schallert and Hare (1991), who placed beliefs and attitudes within the domain of socio-cultural knowledge on the basis of which new experiences and information have been interpreted. In social psychology, Bandura's social cognitive theory (1986) indicated that people's previous experiences and personal beliefs would influence students' behaviors. A prominent view of beliefs is that they are understandings which arise from an individual's life history and educational experiences and which are the basis for value judgments (Dole \& Sinatra, 1994). Also among these perspectives, learners' beliefs about language learning are a 
result of a number of factors that shape one's thinking and belief formation, including past experiences, culture, context, and numerous personal factors (Bernat \& Gvozdenko, 2005). However, Bernart (2006) contended that it is rather the individuals' complex metacognitive structure, as affected by a number of social, cultural, contextual, cognitive, affective, and personal factors that is responsible for shaping the nature and strength of these beliefs.

Meece, Blumenfeld, and Hoyle (1988) described this set of beliefs as being influential in the way people approach and engage. Beliefs also represent knowledge, arouse emotion, and guide behaviors (Harvey, 1986). Students `beliefs systems consist of four underlying factors, which are: (a) beliefs about a contemporary communicative orientation to learning English; (b) beliefs about a traditional orientation to learning English; (c) beliefs about the quality and sufficiency of classroom instruction for learning English and (d) beliefs about foreign-language aptitude and difficulty (Sakui \& Gaies, 1999). According to social learning theory, people acquire knowledge in response to the demands and characteristics of a social context (Rothstein, 1990, p. 95-96). Rotter and Hochreich (1962) contended that learning is affected by an individual's beliefs based on his or her past experiences. In the same learning situation, students sharing the same goals may have different beliefs, or experiences about academic success or failure, which, in turn, influence whether a particular individual will be likely to study or not. The different beliefs or expectancies about success or failure eventually influence students' cognitive functioning and affective responses.

\section{The importance of beliefs}

The importance of taking students belief systems into account has always been stressed by researchers (e.g., Wenden, 1986, 1999; Horwitz, 1988, 1999; Cotterall, 1995; Wen \& Johnson, 1997). Learners bring to the language-learning task a complex set of attitudes, experiences, expectations, and learning strategies (Nyikos \& Oxford, 1993; Benson, 1991; Stone, 1989). Within this variety of beliefs, educational research has indicated that students beliefs about the nature of knowledge and epistemological beliefs can influence learning and comprehension (Jehng, Johnson, \& Andreson, 1995; Ryan, 1984; Cesur, 2011). 
Learners need to believe in the purpose of their own learning and develop positive expectations for their performance, and value success. Goal-oriented, as it always is, learning might be undermined by a number of undesirable goals. As such, Clifford (1984) suggested that learners need to develop their beliefs in control, acknowledging that their actions are responsible for successful performance and that failure is a normal part of learning, which may be used to shape future efforts. However, if learners are not aware of this, passive or negative beliefs toward learning may arise (Johnston \& Winograd, 1985), and as a result, students may develop beliefs about their inability to use effective strategies. From a similar perspective, Pace, Marshall, Horowitz, Lipson, and Lucido,(1989, p.214) also argued that if misconceptions are associated with the students' beliefs, the misconceptions are more resistant to change. In a more recent study, Oz (2007) demonstrated that Turkish EFL learners had a broad range of conceptions both similar to and different from those reported in the current literature. A large number of the EFL learners were found to have misconceptions about learning English language. Some students overcome these misconcept- ions, but others do not.

Understanding learners' cognitive beliefs about language learning and their use of learning strategies, as well as the factors which influence these beliefs and strategies use, is essential to planning appropriate language instruction. Ellis (2001) maintained that it is important to identify learners' beliefs which relate to successful learning and beliefs which have a negative impact on language learning. Ellis suggested that these beliefs might be used to develop self-awareness in learners. Further, Li (2005) suggested that there has been a significant difference between the learners who hold positive beliefs and those who hold negative beliefs about the Role of Rote Learning in vocabulary learning strategies. Ellis (2008) concluded by noting that teachers cannot ignore learner beliefs or their own to help their students become aware of and to evaluate their own beliefs and to address any mismatch in their and their students' beliefs systems. Such evaluation of beliefs can help to establish an understanding of and reconciling any differences in belief systems between teachers and learners. 


\section{Types of learners' beliefs}

In an attempt to identify the types of beliefs held by language learners, Horwitz (1987) administered the Beliefs About Language Learning Inventory (BALLI) to groups of learners. Five general areas of beliefs emerged from the analysis of the responses relating to (1) the difficulty of language learning, (2) aptitude for language learning, (3) the nature of language learning, (4) learning and communication strategies, and (5) motivation and expectations. Wenden (1986) grouped the beliefs she identified in 25 adults enrolled in a part-time advanced-level class at an American university into three general categories: (1) use of the language (for example, the importance of 'learning in a natural way'), (2) beliefs relating to learning about the language (for example, the importance of learning grammar and vocabulary), and (3) the importance of personal factors (i.e., beliefs about the feelings that facilitate or inhibit learning, self-concept, and aptitude for learning). Both of these early studies, then, identified a very similar set of learner beliefs such as beliefs about the need to study grammar. This dominant belief was also reported by Schulz (2001), who found that both Colombian learners of English in Colombia and American learners of foreign languages in the U.S. placed great stress on explicit grammar study and error correction.Learners' beliefs are an important individual difference in second language (L2) learning (Li, 2009). Beliefs are outcomes of both formal and informal learning experiences and determin- ants of subsequent learning (Ryan,1984).Beliefs influence both the process and product of learning and they can be dynamic and situated (Ellis, 2008). Kienhe, Bromm, and Stahl (2008) also indicated the possibility of changing domain-specific epistemological beliefs through ashort-term intervention. However, it questioned the stability and elaborateness of domain-specific epistemological beliefs, particularly when domain knowledge is shallow. Most epistemological belief studies examine the effects of students' beliefs on learning in general. However, there were no record of studies that placed a specific focus on gender and educational academic levels. 
Students educational academic levels and their cognitive beliefs about language learning

Very little research has directly addressed the issue of study level in relevance to beliefs within an educational context (HongNam \& Leavell, 2006; Zhang \& Cui, 2010). Of that which has been conducted, Magogwe and Oliver (2007) found a dynamic relationship between level of schooling (representing age differences) and self-efficacy beliefs. Wenden (1987) suggests that teaching beginning level students the language of metacognition should be given high priority in order to provide the language needed to talk about and receive instruction in learning strategies. Therefore, learning instruction can be given from the beginning, because the instruction is provided in a language that students understand $\left(\mathrm{O}^{\circ}\right.$ Malley \& Chamot, 1995). An analysis has been attempted of the relationship between self-efficacy beliefs and proficiency for students at the different levels of education. The results suggest that age (as represented here by levels of education) relates with regard to self-efficacy beliefs (Magogwe \& Olver, 2007).

The current study which was conducted with students from various levels of tertiary education (1st, 3rd, 5th and 7th level) addresses the deficiency of research exploring the effects of gender on educational academic level of the students. By emphasizing such under-researched areas, it is predicted that educators in Saudi Arabia, and elsewhere, may be assisted in developing appropriate curricula for students of different levels.

\section{The differences between males and females in their Episte- mological beliefs}

Much research has been concerned with describing and classifying the types of beliefs learners hold based on responses to questionnaires, the sources of beliefs, and the situated and dynamic nature of learners' beliefs systems. Somewhat disappointingly, very few studies have examined the effects of gender and students' academic levels on their beliefs towards learning English Although much research has been conducted examining gender differences in beliefs (e.g., Magolda, 1992; Bacon \& Finnemann, 1992; Belenky, Clinchy, Goldberger, \& Tarule,1986;1985),some have argued that there were no important gender differences in the development of epistemological beliefs (Pintrich, 2002). Pintrich (2002) argued that when 
epistemological beliefs are operationalized to incorporate multiple, independent dimensions, as opposed to more holistic developmental models, no gender differences should arise in epistemological beliefs. Therefore, when students are asked to answer questions that focus on one particular domain of epistemological beliefs, there are no differences between boys and girls. Moreover, boys and girls seem to develop their epistemological beliefs at about the same rate.

Nevertheless, gender may play an important role in epistemological reasoning in ways that are undetectable. For example, Belenky et al. (1985; 1986) described 'connected knowing' as a more feminine approach to knowing and learning. This approach advocates a model of teaching whereby teachers are 'participant observers' who model their thinking processes aloud to the class and aid their students in building knowledge not through competing for the 'right' answer, but by building consensus (Hofer \& Pintrich, 1997). However, this connected way of knowing might indeed be associated more with female students, but if male students identified with such a way of knowing, it may mean something quite different for them than for female students. On the other hand, Lummis and Stevenson (1990) affirmed that there were differences in beliefs between males and females. Thus gender affects students' beliefs and consequently it may affect students' performance and achievement in language.

\section{Hypotheses of the research}

1. The students have not positive epistemological beliefs towards English language learning.

2. The students' academic levels have not any impact on their epistemological beliefs towards learning English.

3. The students' gender has not any effect on their epistemological beliefs towards learning English.

\section{Method}

\section{Instruments}

\section{Students' beliefs Questionnaire}

The researchers modified the Beliefs Questionnaire that was used in Sakui and Gaies' (1999) study on assessing Japanese students` beliefs. Participants completed 25-item Questionnaire 
that assessed the beliefs of the participants that were related to their learning of English. Principal Components Analysis, followed by Varimax Rotation, yielded a four-factor solution. These four factors together included 25 positive items. Items (1-11) concerned the beliefs about a contemporary communicative orientation to learning English; items (12-17) represented the beliefs about a traditional orientation to learning English; items (18-22) represented the beliefs about the quality and sufficiency of classroom instruction for learning English; items (23-25) dealt with the beliefs about foreign-language aptitude and difficulty. Respondents answered each item statement using a 4-point Likert-scale that ranged from 1 (Strongly disagree) through 4 (Strongly agree).

\section{Participants}

For standardization the research instrument, a sample of 100 from different students' educational academic levels (40 males and 60 females) was used. The participants in this study included 547 English-major undergraduates (184 males and 363 females); 1st level 144 students ( 47 males \& 97females), 3rd level 122 (26 males \& 96 females, 5th level 108 (42 males \& 66 females and 7th level 173 (69 males \& 104 females) enrolled in a Foreign Languages Department. Participants ranged in age from 19-29 years with a mean of $(M=20.116, S D=1.596)$.

Item validity and internal consistency for beliefs Questionnaire in the current study

The corrected item-total correlations ranged from 0.380 to 0.726 ( $p<0.01$ ), suggesting adequate item validity. As for the corrected item-Subscale 1 , correlation ranged from 0.583 to 0.738 $(p<0.01)$, and the Subscale 2 correlation ranged from 0.488 to $0.746(p<0.01)$. While the Subscale 3 correlation ranged from 0.617 to 0.777 ( $p<0.01$ ), the Subscale 4 correlation ranged from 0.661 to $0.671(p<0.01)$, suggesting adequate item validity. The internal consistency was high for the total scale $(\alpha=0.865)$, as well as for Subscale $1(\alpha=0.863)$ and Subscale $2(\alpha=0.751)$, Subscale $3(\alpha=0.732)$, and Subscale $4(\alpha=0.367)$. The mean total score was 73.580 (S.D.= 11.417). The means were: for Subscale $1(M=35.195, S . D .=6.228)$, for Subscale $2(M=17.755$, S.D. = 3.757), for Subscale $3(M=12.965$, S.D. $=3.537)$, and for Subscale $4(M=7.665$, S.D. $=2.086)$.

\section{0}


Table 1: Correlations between items and total score for each factor for belief questionnaire

\begin{tabular}{|c|c|c|c|c|c|c|c|}
\hline Factors & Items & $\begin{array}{l}\text { Item- } \\
\text { dimension- } \\
\text { Correlations }\end{array}$ & $\begin{array}{l}\text { Item -total } \\
\text { Correlations }\end{array}$ & Factors & Items & Correlations & $\begin{array}{l}\text { Item-total } \\
\text { Correlations }\end{array}$ \\
\hline \multirow{11}{*}{ 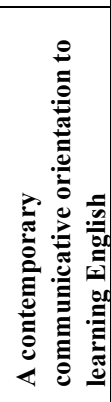 } & 1 & $0.583 * *$ & $0.508 * *$ & \multirow{6}{*}{ 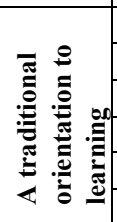 } & 12 & 0.626 ** & 0.538 ** \\
\hline & 2 & 0.738 ** & $0.596 * *$ & & 13 & $0.724 * *$ & 0.540 ** \\
\hline & 3 & $0.668^{* * *}$ & $0.478^{* * *}$ & & 14 & $0.703^{* * *}$ & $0.538 * *$ \\
\hline & 4 & $0.732 * *$ & $0.561 * *$ & & 15 & 0.746 ** & 0.520 ** \\
\hline & 5 & 0.608 ** & $0.497 * *$ & & 16 & $0.733^{* * *}$ & $0.543 * *$ \\
\hline & 6 & 0.631 ** & $0.543^{* * *}$ & & 17 & $0.488^{* * *}$ & $0.365^{* *}$ \\
\hline & 7 & $0.660 * *$ & 0.540 ** & \multirow{5}{*}{ 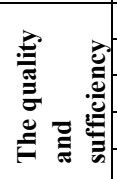 } & 18 & $0.617^{* *}$ & $0.411^{* *}$ \\
\hline & 8 & 0.641 ** & $0.604 * *$ & & 19 & $0.699 * *$ & $0.508^{* * *}$ \\
\hline & 9 & $0.619 * *$ & $0.464 * *$ & & 20 & $0.765^{* *}$ & $0.404 * *$ \\
\hline & 10 & $0.729 * *$ & $0.595^{* * *}$ & & 21 & $0.777 * *$ & 0.471 ** \\
\hline & 11 & $0.572 * *$ & $0.545 * *$ & & 22 & $0.617 * *$ & 0.395 ** \\
\hline & & & & \multirow{3}{*}{ 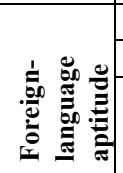 } & 23 & $0.661^{* *}$ & $0.398 * *$ \\
\hline & & & & & 24 & $0.671 * *$ & $0.437 * *$ \\
\hline & & & & & 25 & $0.662 * *$ & $0.307 * *$ \\
\hline
\end{tabular}

Table 1 shows that all the values of item correlations with the total score for each sub factor are statistically significant $(P<0.01$ or $\mathrm{P}<0.05)$ indicating that items of the questionnaire display high internal consistency in measuring the students' beliefs.

Table 2: Internal consistency for beliefs questionnaire sub factors

\begin{tabular}{|l|l|l|l|l|}
\hline Sub factors & Factor1 & Factor2 & Factor3 & Factor4 \\
\hline Factor 1 & 1 & & & \\
\hline Factor2 & $0.489 * *$ & 1 & & \\
\hline Factor3 & $0.228^{* *}$ & $0.344^{* *}$ & 1 & \\
\hline Factor4 & $0.275^{* *}$ & $0.299 * *$ & $0.452^{* *}$ & 1 \\
\hline Total & $0.827 * *$ & $0.757^{* *}$ & $0.630^{* *}$ & $0.572 * *$ \\
\hline
\end{tabular}

$$
P<0.01
$$

Table 2 indicates that there are positive correlations among beliefs for four subscales ranging from $(0.228-0.827)$ indicating that subscales of the Beliefs Questionnaire display high internal consistency in measuring the students' beliefs. . 


\section{Results}

\section{English major students' cognitive beliefs about language learning}

English-major students responded to a 25-items questionnaire with four Liker-type subscales from 1-4. Based on that, the lowest score was 25 and the highest score was 100 . According to the median score for the questionnaire which is 62.5 , results show that students in general have positive cognitive beliefs towards learning English with above average scores $(M=72.9384)$. See Table 3 below.

Table 3: English-major students' epistemological beliefs about learning English

\begin{tabular}{|c|c|}
\hline & Total of Beliefs questionnaire \\
\hline $\mathbf{N}$ & $\mathbf{5 4 7}$ \\
\hline Mean & $\mathbf{7 2 . 9 3 8 4}$ \\
\hline Median & $\mathbf{7 3 . 0 0 0 0}$ \\
\hline Std. Deviation & $\mathbf{9 . 7 9 7 5}$ \\
\hline Minimum & $\mathbf{2 8 . 0 0}$ \\
\hline Maximum & $\mathbf{1 0 0 . 0 0}$ \\
\hline
\end{tabular}

\section{Beliefs across academic levels}

Distinguishing the students at different academic levels, data analysis shows that there are differences between students educational academic levels in their beliefs in subscale $2, \mathrm{~F}$ $(3,543)=11.447, p<0.01)$ and total scores $F(3,543)=2.998, p<$ $0.05)$. To determine the differences between the students' levels (multiple comparisons), Scheffe Test was run across the groups of the students.

Table 4 indicates that there are differences between students' academic levels in subscale 2 (beliefs about a traditional orientation to learning English) and the total score. For subscale 2, there are differences between levels $1(M=18.431, S D=3.4896)$ and level $5(M=16.176, S D=3.6553)$ in favour of level 1 . There are differences between level $3(M=17.467, S D=3.2605)$ and level 7 $(\mathrm{M}=16.601)$ in favour of level $3(\mathrm{SD}=3.3232)$. Differences are also detected between level $1(M=18.431, S D=3.4896)$ and level $7(M=16.601)$ in favour of level 1 . With an estimated effect size for subscale 2 of $\eta 2=0.054$, data indicates that academic levels explained $5.4 \%$ of the variance in the students' beliefs. For the total score of the effect size of $\eta 2=0.01$, data analysis displays 
that academic levels explained $1 \%$ of the variance in the students' cognitive beliefs.

Table 4: ANOVA analysis for differences in beliefs according to the students educational academic levels

\begin{tabular}{|c|c|c|c|c|c|c|c|c|}
\hline & Subscales & & $\begin{array}{l}\text { Sum of } \\
\text { Squares }\end{array}$ & Df & $\begin{array}{c}\text { Mean } \\
\text { Square }\end{array}$ & $F$ & Sig. & $\eta^{2}$ \\
\hline \multirow{15}{*}{ 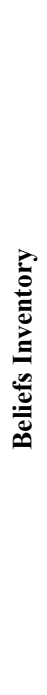 } & \multirow{3}{*}{$\begin{array}{l}\text { (1) beliefs about a } \\
\text { contemporary }\end{array}$} & Between Groups & 110.004 & 3 & 36.668 & \multirow[t]{3}{*}{1.161} & \multirow[t]{3}{*}{.324} & \multirow[t]{3}{*}{---} \\
\hline & & Within Groups & 17154.390 & 543 & 31.592 & & & \\
\hline & & Total & 17264.394 & 546 & & & & \\
\hline & \multirow{3}{*}{\begin{tabular}{|c|} 
(2) beliefs about a \\
traditional orientation to \\
learning English \\
\end{tabular}} & Between Groups & 402.033 & 3 & 134.011 & \multirow[t]{3}{*}{11.447} & \multirow[t]{3}{*}{.000} & \multirow[t]{3}{*}{0.054} \\
\hline & & Within Groups & 6356.812 & 543 & 11.707 & & & \\
\hline & & Total & 6758.845 & 546 & & & & \\
\hline & \multirow{3}{*}{\begin{tabular}{|c|} 
(3) beliefs about the \\
quality and sufficiency of \\
classroom instruction for \\
learning English \\
\end{tabular}} & Between Groups & 24.585 & 3 & 8.195 & \multirow[t]{3}{*}{.709} & \multirow[t]{3}{*}{.547} & \multirow[t]{3}{*}{--- } \\
\hline & & Within Groups & 6274.643 & 543 & 11.556 & & & \\
\hline & & Total & 6299.229 & 546 & & & & \\
\hline & \multirow{3}{*}{$\begin{array}{c}\text { (4) beliefs about foreign- } \\
\text { language aptitude and } \\
\text { difficulty }\end{array}$} & Between Groups & 13.523 & 3 & 4.508 & \multirow[t]{3}{*}{1.109} & \multirow[t]{3}{*}{.345} & \multirow[t]{3}{*}{--} \\
\hline & & Within Groups & 2207.113 & 543 & 4.065 & & & \\
\hline & & Total & 2220.636 & 546 & & & & \\
\hline & \multirow{3}{*}{ Total } & Between Groups & 854.011 & 3 & 284.670 & \multirow[t]{3}{*}{2.998} & \multirow[t]{3}{*}{.030} & \multirow[t]{3}{*}{0.01} \\
\hline & & Within Groups & 51556.602 & 543 & 94.948 & & & \\
\hline & & Total & 52410.614 & 546 & & & & \\
\hline
\end{tabular}

\section{Beliefs across gender}

To examine gender differences in the aspect of beliefs (4 subscales), a t-test for two independent groups was run using beliefs as a dependent variable and gender as the independent variable. Means and standard deviations are reported in Table 5.

T- test revealed that boys achieved significantly higher than girls did in one aspect of the beliefs questionnaire 4 subscales: subscale 3 (beliefs about the quality and sufficiency of classroom instruction for learning English) $\mathrm{t}=2.449$, df $=545, \mathrm{P}<0.05$ ). With an estimated effect size of $\eta 2=0.01$, analysis shows that gender explained $1 \%$ of the variance in the students' beliefs.

In brief, results demonstrated that gender differences were not found in all beliefs subscales except in subscale 3 which was related to beliefs about the quality and sufficiency of classroom instruction for learning English where boys reported more positive beliefs than girls did. 
Number 24, Part 2, April, 2012

Table 5: The differences between males and females in the cognitive beliefs

\begin{tabular}{|c|c|c|c|c|c|c|c|c|c|}
\hline & & Gender & $\mathbf{N}$ & Mean & $\begin{array}{c}\text { Std. } \\
\text { Deviation }\end{array}$ & $t$ & Df & Sig & $\eta^{2}$ \\
\hline \multirow{10}{*}{ 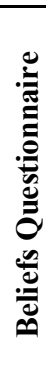 } & \multirow[b]{2}{*}{ Subscale(1) } & Male & 184 & 34.9837 & 5.9895 & \multirow[t]{2}{*}{-1.046} & \multirow[t]{2}{*}{545} & \multirow[t]{2}{*}{.296} & \multirow[t]{2}{*}{---- } \\
\hline & & Female & 363 & 35.5160 & 5.4278 & & & & \\
\hline & \multirow[b]{2}{*}{ Subscale(2) } & Male & 184 & 17.0326 & 3.3696 & \multirow[t]{2}{*}{-.754} & \multirow[t]{2}{*}{545} & \multirow[t]{2}{*}{.451} & \multirow[t]{2}{*}{------ } \\
\hline & & Female & 363 & 17.2727 & 3.5933 & & & & \\
\hline & \multirow[b]{2}{*}{ Subscale(3) } & Male & 184 & 12.7989 & 3.2706 & \multirow[t]{2}{*}{2.449} & \multirow[t]{2}{*}{545} & \multirow[t]{2}{*}{.015} & \multirow[t]{2}{*}{0.01} \\
\hline & & Female & 363 & 12.0496 & $\mathbf{3 . 4 3 5 7}$ & & & & \\
\hline & \multirow[b]{2}{*}{ Subscale(4) } & Male & 184 & 8.1304 & 1.9032 & \multirow[t]{2}{*}{.186} & \multirow[t]{2}{*}{545} & \multirow[t]{2}{*}{.852} & \multirow[t]{2}{*}{----- } \\
\hline & & Female & 363 & 8.0964 & 2.0743 & & & & \\
\hline & \multirow{2}{*}{$\begin{array}{l}\text { Total of } \\
\text { beliefs }\end{array}$} & Male & 184 & 72.9457 & 9.8279 & \multirow[t]{2}{*}{.012} & \multirow[t]{2}{*}{545} & \multirow[t]{2}{*}{.990} & \multirow[t]{2}{*}{----- } \\
\hline & & Female & 363 & 72.9347 & 9.7956 & & & & \\
\hline
\end{tabular}

Discussion

This study provided an overview about language learning beliefs held by English-major learners in a Saudi Arabian University. The main purpose of this study was to investigate the effects of gender and educational academic levels of Englishmajor students on their beliefs towards learning English. Findings of the present study are discussed in accordance with the three research questions respectively.

English-major students' epistemological beliefs about language learning

The results indicated that students had positive epistemological beliefs towards learning English language. This might indicate that the students' have fair awareness about the importance of learning English language. As such, this awareness implies that the students have high motivation to study well and help to constitute strongly positive beliefs towards studying English as a language and as a discipline. This result is consistent with the results of Ariogul et al. (2009) who documented that communication and positivity between teachers and students could be the key to successful language learning. So the researchers suggest that a kind of strong relationship between teachers and students should be found to increase and encourage the students' positive epistemological beliefs towards learning English language.

Impact of educational academic levels on English-major students' beliefs toward language learning

The results indicated that there were differences in the beliefs about English language learning across students`academic levels 
in subscale 2 concerned with traditional orientation to learning English. The total score was in favour of the beginner academic levels. This result is inconsistent with the results of Zhang \& Cui, (2010) who concluded that the difference was in the favour of the advanced academic level. This result is also inconsistent with the results of Hong-Nam \& Leavell's (2006) study which documented that students in the intermediate level reported more use of learning strategies than beginning and advanced academic levels. Furthermore, findings of other studies suggested that beliefs might vary based on the stage of learning (Horwitz,1999). The beginnerlevel students were more likely to believe in the importance of their own learning EFL and its reflection on their study and their career in general. So, the teachers should be caring for the beginner-level students' beliefs to develop and keep up their positive beliefs towards learning English. Not only the teachers but also the students' academic advisors should have a kind of awareness of those beginner-level students' beliefs and try to develop these positive beliefs.

Impact of gender on the epistemological beliefs towards language learning

With respect to the third research question, the results indicated that there were no significant differences between means of beliefs. However, subscale 3 (beliefs about the quality and sufficiency of classroom instruction for learning English) according to gender was in favour of males. Such a result explicitly demonstrated that the mean score for males' beliefs (mean $=12.80)$ was significantly higher than the females' mean score $($ mean $=12.05$ ) in subscale 3 . This finding is partially consistent with the previous research results of (Üstünel \& Samur, 2010) which also favoured males as more frequently having positive beliefs about the quality and sufficiency of classroom instruction for learning English in comparison with those of females. On the other hand, findings of the present study of gender impact were inconsistent with several studies which indicated that female beliefs were significantly higher than the males (e.g., Magolda, 1992; Bacon \& Finnemann, 1992; Belenky, et al., 1985; 1986; Hashemi, 2011). Moreover, it is inconsistent with the results of Pintrich (2002) who argued that there were no differences between boys and girls in terms of beliefs about

\section{5}

Journal of Arabic Studies in Education \& Psychology(ASEP) 
language learning and they seemed to develop their beliefs at about the same rate. In reference to the current context conditions, this result might be attributed to the relatively better qualified male teachers in the Department of Foreign Languages; so male students might be influenced by the attitudes of their professors and their teaching styles.

Based on these findings, language teachers at the tertiary level can implement and discuss positive instructional practices and realistic expectations in the classroom. Raising awareness about the effects of factors related to gender and academic levels would help the teachers to understand and alleviate negative preconceived beliefs of some language learners. For example the teachers of English departments can activate English language club activities and hold student meetings to encourage students use of English language and increase their awareness of the importance of English language.

\section{Conclusion}

The present study findings provided a comprehensive overview of the effects of English-major students' gender and academic levels on their beliefs towards learning English. Gender was found to have no significant effect on students' cognitive beliefs about English language learning except in subscale 3; i.e., beliefs about the quality and sufficiency of classroom instruction for learning English. This finding partially aligns with previous studies which found no significant differences between males and females in beliefs questionnaire and its subscales except in subscale 3 . Thus, gender is not always a determining factor in beliefs about English language learning.

Implications of the present study draw our attention once again that awareness about self beliefs can be considered in different ways in language education. A first step is to make learners aware of their learning beliefs and show them their positive and negative beliefs. The knowledge about their English language learning beliefs helps students to understand why learning is sometimes difficult for them. The results of this study indicate that more research is needed in the area of English language learning beliefs and their relation to gender. 
From a practical point of view, teachers need to know not only what their learners believe about English language learning, but also whether their beliefs are positive or negative and how negative beliefs can be discovered and rectified. Future research might consider investigating the effects of teachers' beliefs on the students' beliefs as well as the effects of teachers' beliefs on their own teaching methods. Also, further directions can include investigating the effects of students' beliefs on their English language learning strategies.

\section{References}

Alexander, R.A., Schallert, D.L., \& Hare, V.C. (1991). Coming to terms: how researchers in learning and literacy talk about knowledge. Review of Educational Research, 61, 315-343.

Amuzie, G.L., \& Winke, P. (2009). Changes in language learning beliefs as a result of study abroad. System, <http://dx.doi.org/10.1016/ j.system.2009.02.011>.

Ariogul, S., Unal, D.C., \& Onursal, I. (2009). Foreign language learners' beliefs about language learning: a study on Turkish university students. Procedia Social and Behavioral Sciences, 1,1500-1506.

Bacon, S.M.C., \& Finnemann, M.D. (1992). Sex differences in selfreported beliefs about foreign language learning and authentic oral and written input. Language Learning, 42 (4), 471-495.

Bandura, A. (1986). Social foundations of thought and action: A social cognitive theory. Englewood Cliffs, New Jersy: Prentice-Hall.

Barcelos, A.M.F. (2003). Researching beliefs about SLA: a critical review. In: Kalaja, P., Barcelos, A.M.F. (Eds.), Beliefs about SLA: New Research Approaches. Kluwer Academic Publishers, London, $7-$ 33.

Magolda, M. B. (1992). Knowing and reasoning in college: Genderrelated patterns in students' intellectual development. San Francisco: Jossey-Bass.

Belenky, M. F., Clinchy, B. M., Goldberger, N. R., \& Tarule, J. M. (1986). Women's ways of knowing: The development of self, voice, and mind. Belenky, M.F. (Eds.), Knowledge, Difference, and Power; Essays inspired, 205-247. New York, NY: Basic Books.

Benson, M.J. (1991). Attitudes and motivation towards English: a survey of Japanese freshmen. RELC Journal, 22 (1), 35-45. 
Bernat, E. (2006). Assessing EAP learners' beliefs about language learning in the Australian context. Asian EFL Journal, 8 (2), 202-227.

Bernat, E., \& Gvozdenko, I., (2005). Beliefs about language learning: Current knowledge, pedagogical implications and new research directions. http://tesl-ej.org/ej33/a1.html

Bulut, T., \& Durak, S. (2002). The difference between the perceptions of the students and their teachers'. 1st International Symposium on Modern Approaches, Methods, and ELT Problems, SDU, Isparta.

Cesur, M. O. (2011). Can language learning strategies predict Turkish university prep class students' achievement in reading comprehension? Procedia Social and Behavioral Sciences, 15, 19201924.

Chang, L.Y.H. (2007). The influences of group processes on learners' autonomous beliefs and behaviours. System, 35, 322-337.

Clifford, M.M. (1984). Thoughts on a theory of constructive failure. Educational Psychologist, 19, 108-120.

Clinchy, B. M., Belenky, M. F., Goldberger, N., \& Tarule, J. M. (1985). Connected education for women. Journal of Education, 167, 28-43.

Cotterall, S., (1995). Readiness for autonomy: investigating learners' beliefs. System 23 (2), 195-205.

Dole, J.A., \& Sinatra, G.M., (1994). Social psychology research on beliefs and attitudes: implications for research on learning from text. In: Garner, A., \& Alexander, P.A. (Eds.), Beliefs About Text and Instruction with Text. Lawrence Erlbaum, Hillsdale, New Jersy, 245264.

Ellis,R.(2001).Individual differences in second language learning. Retrieved February 12, 2004 fromhttp://english.nccu.edu.tw/academic /rodellis/lect3.doc

Ellis, R. (2008). Learner Beliefs and Language Learning. Asian EFL Journal, 10 (4), 1-27.

Flavell, J. H. (1979). Metacognition and cognitive monitoring: A new area of cognitive-developmental inquiry. American Psychologist, 34 (10), 906-911.

Flavell, J. H. (1985). Cognitive Development, $2^{\text {nd }}$ ed. New Jersy: Prentice Hall. 
Flavell, J.H. (1976). Metacognitive aspects of problem solving. In: Resnik, B. (Ed.), The Nature of Intelligence. Lawrence Erlbaum, Hillsdale, NJ.

Flavell, J.H. (1987). Speculation about the nature and development of metacognition. In: Weiner, F.E., Kluwe, R.H. (Eds.), Metacognition, Motivation and Understanding. Lawrence Erlbaum, Hillsdale, New Jersy, 1-29.

Gao, X. (2008). Forget Chinese - let's think only in English! Chinese netizens debating the best ways to learn English in China. Changing English 15, 435-444.

Green, J. (1993). Students' attitudes toward communicative activities: Do enjoyment and effectiveness go together? The Modern Language Journal, 77, 1-10.

Hashemi; M. (2011). The impact of gender on language learning strategies of IRANIAN EFL learners. International Journal of Academic Research, 3. ( 2), 280-285.

Harvey, O. J. (1986). Belief systems and attitudes toward the death penalty and other punishments. Journal of Psychology, 54, 143-159.

Hofer, B. K., \& Pintrich, P. R. (1997). The development of epistemological theories: Beliefs about knowledge and knowing and their relation to learning. Review of Educational Research, 67, 88140.

Hong-Nam, K., \& Leavell, A. (2006). Language learning strategy use of ESL students in an intensive English learning context. System, 34,399-415

Horwitz, E.K. (1987). Surveying student beliefs about language learning. In: Wenden, A., Rubin, J. (Eds.), Learner Strategies in Language Learning. Prentice Hall, Englewood Cliffs, New Jersy, 119-129.

Horwitz, E.K. (1988). The beliefs about language learning of beginning university foreign language students. The Modern Language Journal. 72, 283-294.

Horwitz. E.K. (1999). Cultural and situational influences on foreign language learners' beliefs about language learning: a review of BALLI studies. System, 27, 557-576.

Hsiao, T., Oxford, R., (2002). Comparing theories of language learning strategies: a confirmatory factor analysis. The Modern Language Journal, 86 (3), 368-383. 
Jehng, J. C., Johnson, S. D., \& Andreson, R.C. (1995). Schooling and students` epistemological Beliefs about learning. Contenporary Educational Psychology, 18, 73-85.

Johnston, P.H., \& Winograd, P.N. (1985). Passive failure in reading. Journal of Reading Behaviour, 17, 279-301.

Kern, R.G. (1995). Students' and teachers' beliefs about language learning. Foreign Language Annals, 28, 71-91.

Kienhe, D., Bromm, R., \& Stahl, E. (2008). Changing Epistemological Beliefs: The Unexpected impact of a Short-Term. British Journal of Educational Psychology, 78 (4), 545-565.

Li, L. S. (2009). Second Language Learners` Beliefs about Grammar Instruction and Error. Modern Language Journal, 93 (1), 91- 104.

Li, X. (2005). An Analysis of Chinese EFL learners' Beliefs about the Role of Rote Learning in Vocabulary Learning Strategies, Asian EFL Journal. Complete reference list of this dissertation available at htt// www. efl- journal.com/xiuping_11-05_thesis.pdf. 109-110.

Little, D., \& Singleton, D. (1990). Cognitive style and learning approach. In: R. Duda and P. Riley (Eds.), Learning Styles, 11-19. Nancy, France: University of Nancy.

Lummis, M., \& Stevenson, H. W. (1990). Gender Differences in Beliefs and Achievement: A Cross-Cultural Study. Developmental Psychology, 26(2), 254-263.

Magogwe, J. M., \& Oliver, R. (2007). The relationship between language learning strategies, proficiency, age and self-efficacy beliefs: A study of language learners in Botswana. System, 35, 338352.

Mantle-Bromley, C. (1995). Positive attitudes and realistic beliefs: Links to proficiency. The Modern Language Journal, 79, 372-386.

Meece, J. L., Blumenfeld, P. C., \& Hoyle, R. H. (1988). Students' goal orientations and cognitive engagement in classroom activities. Journal of Educational Psychology, 80, 514-523.

Na, P. P.Q. (2007). Some Strategies for Teaching English to Multi-level Adult ESL Learners: A Challenging Experience in Australia, Asian EFL Journal, 9 (4), 306 - 322.

Nyikos, M., \& Oxford, R., (1993). A factor analytic study of language learning strategy use: interpretations from information-processing 
theory and social psychology. The Modern Language Journal, 77, 1121.

O’Malley, J., \& Chamot, A. (1995). Learning Strategies in Second Language Acquisition. (4 ${ }^{\text {th }}$ Ed.) New York: Cambridge University Press.

Oxford, R. (1993). Research on second language learning strategies. Annual Review of Applied Linguistics, 13, 175-187.

Oz, H. (2007). Understanding Metacognitive Knowledge of Turkish EFL Students in Secondary Education. Online Submission, NovitasROYAL, 1(2), 53-83.

Pace, A. J., Marshall, N., Horowitz, R., Lipson, M., \& Lucido, P. (1989). When Prior knowledge doesn't facilitate text comprehension: An examination of some of the issues. In: S. McCormick, J. Zutell, P.L. Scharer, \& P.R. O'Keefe (Eds), Cognitive and social perspectives for literacy research and instruction, 213-224. Chicago, IL: The National Reading Conference, Inc.

Pintrich, P. R. (2002). Future challenges and directions for theory and research on personal epistemology. In: B. K. Hofer, \& P. R. Pintrich (Eds.), Personal epistemology: The psychology of beliefs about knowledge and knowing, 389-414. Mahwah, NJ: Erlbaum.

Richardson, V. (1996). The role of attitude and beliefs in learning to teach. In: J. Sikula, T. J. Buttery, \& E. Guyton (Eds.), Handbook of research on teacher education: A project of the association of teacher educators (2nd ed. 102-119). New York: Macmillan.

Rothstein, P. R. (1990). Educational Psychology. New York: McGrawHill, Inc.

Rotter, J. B., \& Hochreich, D. J. (1962). Personality. Glenview, IL: Scott Foresman.

Ryan, M.P. (1984). Monitoring text comprehension: individual differences in epistemological standards. Journal of Educational Psychology, 76, 248-258.

Sakui, K., \& Gaies, S.J. (1999). Investigating Japanese learners' beliefs about language learning. System, 27, 473-492.

Schulz, R. (2001). Cultural differences in student and teacher perceptions concerning the role of grammar instruction. The Modern Language Journal, 85, 244-58. 
Stone, R. (1989). Considerations for Japanese ESL learners prior to intensive ESL programs in the United States: 3 case studies in awareness and motivation. Cross Currents, 15 (2), 39-49.

Tanaka, K., \& Ellis, R., (2003). Study-abroad, language proficiency, and learner beliefs about language learning. JALT Journal, 25 (1), 63-83.

Twyford, C.W. (1988). Age-related factors in second language acquisition. Focus, 2.

Üstünel,E., \& Samur, E. (2010). Examining the relationship between two year vocational school students' beliefs about language learning and their academic success. Procedia Social and Behavioral Sciences, 2, 3489-3493.

Wen, Q., \& Johnson, R.K. (1997). L2 learner variables and English achievement: a study of tertiary-level English majors in China. Applied Linguistics, 18, 27-48.

Wenden, A. (1986). What do second language learners know about their language learning? A second look at retrospective accounts. Applied Linguistics, 7, 186-201.

Wenden, A. (1998). Metacognitive knowledge and language learning. Applied Linguistics, 19, 515-537.

Wenden, A. (2001). Metacognitive knowledge in SLA: the neglected variable. In: Breen, M. (Ed.), Learner Contributions to Language Learning. 44-64. Pearson Education Limited, Harlow.

Wenden, A.L. (1999). An introduction to metacognitive knowledge and beliefs in language learning beyond the basics. System, 27, 435-441.

White, C. (1999). Expectations and emergent beliefs of self-instructed language learners. System, 27, 443-457.

Zhang, X., \& Cui, G. (2010). Learning beliefs of distance foreign language learners in China: A survey study. System, 38, 30-40.

\section{溇溇溇溇溇}

